\begin{tabular}{|l|l|}
\hline $\begin{array}{l}\text { 2. To: (Receiving Organization) } \\
\text { Distribution }\end{array}$ & $\begin{array}{l}\text { 3. From: Coriginating Organization) } \\
\text { Analytical Services, 5A620 }\end{array}$ \\
\hline 5. Proj./Prog./Dept./Div.: & $\begin{array}{l}\text { 6. Design Authority/ Design Agent/Cog } \\
\text { Engr.: }\end{array}$ \\
24l-AN Vent Upgrades/TWRS & J. R. Kriskovich \\
\hline
\end{tabular}

8. Originator Remarks:

\#ETN-95-0031

11. Receiver Remarks: 11A. Design Basel ine Document? [x] Yes [ ] No

\author{
4. Related EOT No.: \\ 7. Purchase Order No.: \\ $n / a$
}

9. Equip./Component No.:

$n / a$

10. System/Bldg./Facility:

24I-AN

12. Major Assm. Dwg. No.:

$\mathrm{H}-2-85646$

13. Permit/Permit Application No.: $n / a$

14. Required Response Date:

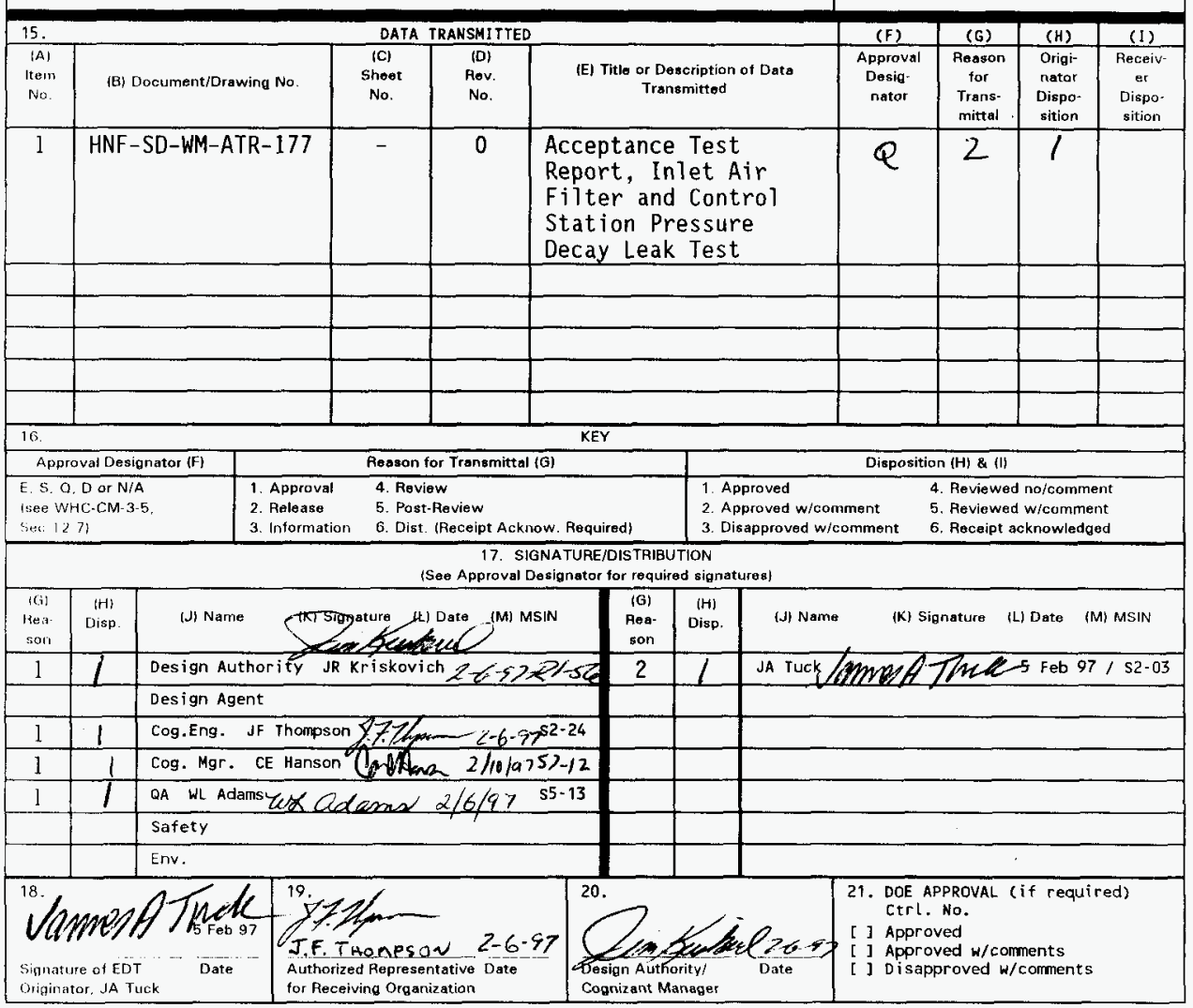

BD-7400-172-2(05/96) GEF097 


\title{
Acceptance Test Report, Inlet Air Filter and Control Station Pressure Decay Leak Test
}

\author{
J.A. Tuck
}

Fluor-Daniel Hanford Company, Richland, WA 99352

U.S. Department of Energy Contract DE-AC0\%-96RL13200

\author{
EDT: 617369 \\ Org Code: 5 A620 \\ B\&R Code: EW3120071 \\ UC: 506 \\ Charge Code: E20882/P5A400 \\ Total Pages: 30
}

Key Words: ventilation, upgrades, flow control, primary confinement, nuclear air treatment, leak testing, ASME N509, ASME N510

Abstract: This is the acceptance test report for pressure decay leak tests performed on Tank Farm primary ventilation system inlet air filter and control stations, following their installation in the field and prior to acceptance for beneficial use.

IRADEMARK DISCLAIMER. Reference herein to any specific comercial product, process, or service by trade name, trademark, manufacturer, or otherwise, does not necessarily constitute or inoply its endorsement, recormendation, or favoring by the United States Government or any agency thereof or its contractors or subcontractors.

Printed in the United States of America. To obtain copies of this document, contact: WhC/BCS Document Control Services, P.O. Box 1970, Mailstop H6-08, Richland WA 99352, Phone (509) 372-2420; Fax (509) 376-4989.
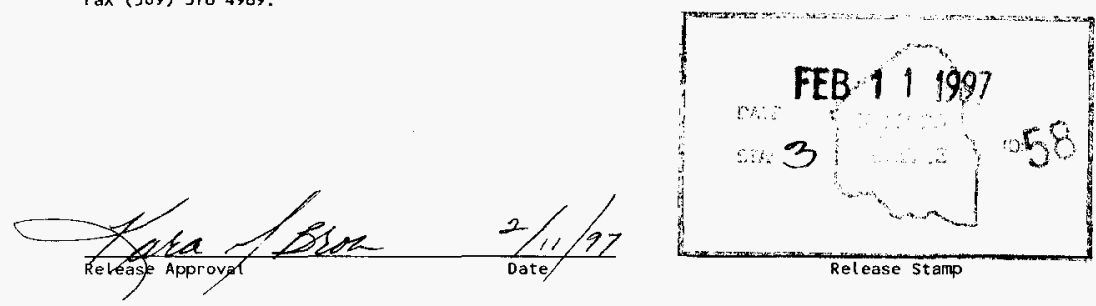

\section{Approved for Public Release}


HNF-SD-WM-ATR-177 Rev. 0

\title{
ACCEPTANCE TEST REPORT, \\ INLET AIR FILTER AND CONTROL STATION \\ PRESSURE DECAY LEAK TEST
}

\begin{abstract}
CONTENTS
ACCEPTANCE TEST REPORT . . . . . . . . . . . . . . . . . . . 1

INTRODUCTION . . . . . . . . . . . . . . . . . . . . . . . 1

RESULTS AND DISCUSSION . . . . . . . . . . . . . . . . . . . . . 1

CONCLUSION . . . . . . . . . . . . . . . . . . . . . . . . . . 2

REFERENCES . . . . . . . . . . . . . . . . . . . . . . . . . . 2

APPENDIX A: ACCEPTANCE TEST PROCEDURE, WHC-SD-WM-ATP-177 . . . . . . . A-1

APPENDIX B: TEST DATA . . . . . . . . . . . . . . . . . . . . . . B-1
\end{abstract}




\section{ACCEPTANCE TEST REPORT}

\section{INTRODUCTION}

Seven primary ventilation system air inlet filter station assemblies were installed as part of a ventilation upgrade in the 241-AN Tank Farm (WHC 1996a). A pressure decay test was performed as part of acceptance testing on each of the completed installations, in accordance with an acceptance test procedure (WHC 1996b). The procedure is reprinted and attached as Appendix $A$ to this document, for reference. The pressure decay tests were performed 29-30 October 1996 and 24 January 1996, in the 241-AN Tank Farm. The cognizant test engineer was Jack F. Thompson of SGN Eurisys Services Company. The Test Director was Robert T. Skamser of Lockheed Martin Hanford Company. Additional support was provided in the field by Fluor-Daniel Northwest Company and East Tank Farms Operations.

The decay test procedure includes a description of the test and a list of equipment required, as well as specifying an allowable leak rate and documenting its basis in ASME N509 (ASME 1989). Briefly, the test consisted of the following elements:

: Isolate/seal off the air station from the tank and the atmosphere;

- Perform visual inspections of ductwork, housings, filters, connections, and gaskets, and seals for signs of damage or improper installation;

- Pressurize the air station to +7.5 in. w.g., and record pressure and temperature readings once a minute for up to 15 minutes;

- Calculate a leak rate based on readings, and compare with specified acceptance criterion of $1.64 \mathrm{ft}^{3} / \mathrm{min}$;

- If unit exceeds acceptance criterion (fails), locate and repair leaks and retest as often as necessary;

- Document results.

Additional testing to be conducted on the inlet air control stations, as part of the 241-AN upgrade, includes an operational test (WHC 1996c). Flow Controller and Vacuum Breaker assemblies were acceptance tested prior to installation in 241-AN Tank Farm (WHC 1996d).

\section{RESULTS AND DISCUSSION:}

The results of testing the Air Stations are tabulated below. The test pressure, as specified in the procedure, was +7.5 in. w.g. All units passed the pressure decay criterion for acceptance, as specified in the procedure.

The use of a bubble solution provided additional visual evidence that there was no significant leakage from any of the gaskets or connections on the tank side of the system, i.e. between the prefilter and the isolation butterfly valve. Note that the riser extension connecting the air inlet station to the tank was previousiy leak-tested in the shop during the process of fabrication (ref. WHC 1996a \& 1996b). No test exceptions were found during the course of testing, and no retest was necessary on any of the units. 
HNF-SD-WM-ATR-177 Rev. 0

\begin{tabular}{|c|c|}
\hline & SUMMARY OF TEST RESULTS \\
\hline TANK/TEST NUMBER & AVERAGE TOTAL HOUSING LEAKAGE RATE, $\mathrm{ft}^{3} / \mathrm{min}$ \\
\hline $241-A N-101$ & 0.09 \\
\hline $241-A N-102$ & 1.06 \\
\hline $241-A N-103$ & 0.04 \\
\hline $241-A N-104$ & 0.04 \\
\hline $241-A N-105$ & 0.11 \\
\hline $241-A N-106$ & 0.03 \\
\hline $241-A N-107$ & 0.05 \\
\hline
\end{tabular}

\section{CONCLUSION}

All seven air inlet station assemblies passed the acceptance test at less than the allowable leak rate of $1.64 \mathrm{ft}^{3} / \mathrm{min}$, and are therefore acceptable for use.

\section{REFERENCES}

NOTE: See acceptance test procedure (WHC 1996b, or Appendix A of this document) for additional references.

WHC, 1996a, Air Control Station, H-2-85646, Rev 0, Westinghouse Hanford Company, Richland, Washington.

WHC, 1996b, Acceptance Test Procedure, Inlet Air Filter and Control Station Pressure Decay Leak Test, WHC-SD-WM-ATP-177, Westinghouse Hanford Company, Richland, Washington.

WHC, 1996c, Operational Test Plan for 241-AN In7et Air Control Stations, WHCSD-WM-0TP-215, Westinghouse Hanford Company, Richland, Washington.

WHC, 1996d, Acceptance Test Report, Flow Controller and Vacuum Breaker Assemblies, WHC-SD-WM-ATR-178, Westinghouse Hanford Company, Richland, Washington. 
HNF-SD-WM-ATR-177 Rev. 0

\section{APPENDIX A: ACCEPTANCE TEST PROCEDURE, WHC-SD-WM-ATP-177, INLET AIR FILTER AND CONTROL STATION PRESSURE DECAY LEAK TEST (REPRINTED)}

\subsection{INTRODUCTION}

\subsection{PURPOSE AND SCOPE}

Seven primary ventilation system inlet air filter and control station assemblies are to be fabricated and installed as part of an upgrade of the 241-AN Tank Farm ventilation system (WHC 1995; WHC 1996a). After the inlet air control stations are installed, a pressure decay leak test will be performed in the field as part of acceptance testing.

The following acceptance test procedure is adopted from a pressure decay leak test performed in support of the 241-AW vent upgrades (WHC 1996b). The procedure is designed to address the requirements specified in ASME N510-1989, Testing of Nuclear Air Treatment Systems, Section 6.5.3, "Pressure Decay Method".

The boundary being verified includes all connections, ports, and access doors between the air inlet and the 12-in. isolation butterfly valve (Item \#5 on $\mathrm{H}-2-85646)$. While the flow controller and connections on the inlet or "clean" side of the HEPA filter seal are noncritical, they are part of the same pressure boundary as the rest of the inlet air control station and are therefore included in the acceptance test. The scope of this test does not include the actual field connection to the tank riser; the isolation valve and riser adapter assembly are leak-tested separately (i.e., outside the scope of this procedure) per General Note \#12 on $\mathrm{H}-2-85646$.

\subsection{REFERENCES}

ASME, 1989a, Nuclear Power Plant Air-Cleaning Units and Components, ASME N509-1989, American Society of Mechanical Engineers, New York.

ASME, 1989b, Testing of Nuclear Air Treatment Systems, ASME N510-1989, American Society of Mechanical Engineers, New York.

WHC, 1995, Ventilation Tank Primary System (VTP) 0\&M System P\&ID, H-14-020101, Westinghouse Hanford Company, Richland, Washington.

WHC, 1996a, Air Control Station, H-2-85646, Westinghouse Hanford Company, Richland, Washington.

WHC, 1996b, Acceptance Test Report, 241-AW Inlet Filter Station Pressure Decay Test, WHC-SD-WM-ATR-169, Rev. 0, Westinghouse Hanford Company, Richland, Washington.

\subsection{RESPONSIBILITIES}

The following personnel shall be involved in the Acceptance Test, 1isted with descriptions of their responsibilities: 


\subsubsection{Cognizant Engineer}

- Represents TWRS Equipment Engineering, or the design authority for the inlet air control station prior to turnover.

- Prepares the ATP document and revisions.

- Prepares or assists in preparing exceptions to the ATP.

- Appoints a Test Director.

- Provides technical support if required during the Acceptance Test.

- Identifies or approves equipment and facilities used for the test.

- Approves acceptability of test activities and results.

- Prepares the Acceptance Test Report (ATR) and revisions.

\subsubsection{Test Director (or Designee)}

- Schedules personnel and other resources needed for the Acceptance Test and oversees test activities.

- Obtains materials needed for the Acceptance Test.

- Directs the test personnel and test activities.

- Completes the associated data sheets for each tested housing/duct assembly.

- Reviews and approves exceptions to the ATP.

- Witnesses and signs each step of the ATP, or designates a responsible person to do so.

- Is responsible for personnel safety during performance of the test.

\subsubsection{Quality Assurance}

- Reviews and approves the ATP, ATR, and revisions.

- Verifies completion of the acceptance test by review of the data sheets.

\subsubsection{Safety Assurance}

- Reviews and approves the ATP, and revisions.

- Inspects test equipment or facilities, if requested, to resolve safety concerns.

\subsubsection{0ther}

- Sheet Metal and Operations personnel will be required to support this test. 


\subsection{DESCRIPTION}

The test procedure specifies an allowable leak rate and documents its basis in ASME N509 (ASME 1989a). Briefly, the test consists of the following elements:

- Visually inspect equipment for obvious signs of misalignment, damage, or functional problems;

- Isolate or seal off all openings;

- Pressurize the inlet air control station, allow to stabilize at a specified test pressure, and record pressure and temperature readings (as well as elapsed time) while pressure decays for a specified period of time or until the specified decay pressure is reached;

- Calculate a leak rate per ASME N510 (ASME 1989b) in standard $\mathrm{ft}^{3} / \mathrm{min}$ (SCFM) based on data, and compare with specified acceptance criterion;

- If unit exceeds acceptance criterion (fails), locate and repair leaks and retest as often as necessary;

- Document the test resuits in a test report.

\subsection{TEST CONDITIONS AND EQUIPMENT REQUIRED}

Testing shal1 be conducted in the 241-AN Tank Farm. Required test equipment includes:

- Test setup per Figure 1.

- Calibrated pressure measurement device, accurate to \pm 0.1 in. w.g., approximate range of 0 to $10 \mathrm{in.w.g.}$

- Calibrated barometer, accurate to $\pm 0.01 \mathrm{in}$. Hg, or use Hanford weather station data.

- Calibrated temperature indicator, accurate to $\pm 1.0^{\circ} \mathrm{F}$.

- Compressed air source (or blower), pressure reducer (may be a damper if a blower is used), isolation valve, and safety relief mechanism to protect housing assembly from pressures in excess of test pressure.

- Miscellaneous fittings to connect instruments and equipment to filter housing. There are two $1-i n$. NPT female ports and one $3 / 4-$ in. NPT male port to connect instruments and the air source (see Figure 1 for recommended instrument/equipment locations).

- Temporary blankoffs, duct tape, sealants or other temporary materials necessary to seal inlets on flow controller and vacuum breaker, and free end of flex connection. 
USE 1-IN. FEMALE NPT CONNECTIDN DN SIDE DF HOUSING FOR AIR SUPPLY (CDNSISTING OF SAFETY RELIEF DEVICE,

ISDLATIDN VALVE, AND PRESSURE REDUCER)

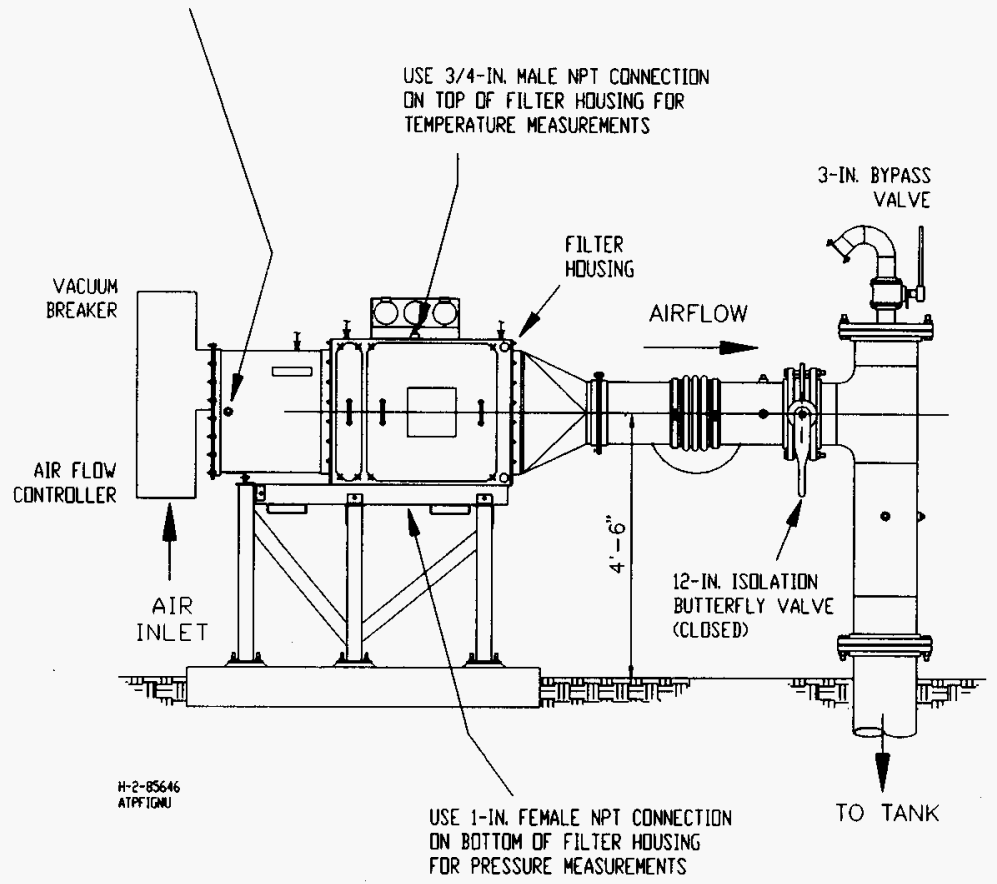

FIGURE 1. Inlet Air Filter and Control Station Pressure Decay Leak Test Setup. 


\subsection{ACCEPTANCE TEST PROCEDURE}

Testing shall be conducted by the responsible personnel as defined in Section 1.3. Blank field copies of the Test Execution Data and Test Exception Sheets (Section 3.0 and 4.0 ) shall be obtained for the acceptance test. At least one set of Data Sheets is needed for each assembly tested.

The test director (or designee) shall initial and date each step of the Test Execution Data Sheets as they are completed. This signifies ACCEPTANCE, i.e., that the step has been successfully completed per the procedure, with data required by the procedure having been recorded in the adjacent data and comments column, including units of measure where applicable, and acceptance criteria having been met.

Test exceptions shall be resolved during testing. Each exception and its resolution shall be documented on a copy of the "Record of Test Exception" sheet provided in Section 4.0 of this ATP, one sheet per exception. Each exception may apply to more than one assembly tested if the same problem is encountered more than once during testing. Exceptions shall also be referenced in the COMMENTS column of Test Execution Data Sheet at the corresponding ATP step.

If an exception requires equipment adjustment or modification, or the Test Director determines continued operation may result in an unsafe situation, the equipment shall be shut down in a safe condition and testing delayed or terminated. Testing shall be resumed by the Test Director only after the exception is resolved and documented, at a logical starting point in the procedure that will provide retesting of the item that initiated the exception or concern.

Test exceptions are typically prepared by the Cognizant Engineer, but may be prepared by the Test Director or others with the technical assistance and approval of the Cognizant Engineer.

Exceptions shall be approved by the Test Director and the Cognizant Engineer.

The notated field copy of the Test Execution Data Sheet, along with Test Exception Sheets if used, shall be treated as quality records for use in compiling or revising a test report.

The Acceptance Test Report (ATR) shall include a copy of this ATP, completed data and exception sheets, a summary of the test results, observations, and conclusions.

\subsection{DETERMINATION OF ACCEPTANCE CRITERION: ALLOWABLE LEAK RATE}

The allowable leak rate $\left(L_{s}\right)$ acceptance criterion for the inlet air control station housing/duct assembly is based on ASME N509-1989 (ASME 1989a) Nonmandatory Appendix B, Table B-3, for Leakage Class II equipment, and equals:

$$
L_{s} \text {, in SCFM }=(a / A)(P Q) / 100
$$


where: $\quad P=$ allowable percent leakage $=1.00$ (Leakage Class II, ductwork), or: $=0.20$ (Leakage Class II, housing)

$Q=$ system rated flow $=400$ SCFM

$A=$ surface area of total system ductwork $=123.9 \mathrm{ft}^{2}$

$a=$ surface area of the inlet air control station, including flow controller, test section, filter housing, transition, and connecting duct $=64.2 \mathrm{ft}^{2}$

Values for $Q, A$, and a were calculated previously for the 24l-AW design (WHC 1996b), and are similar for the 241-AN installations. The "total system ductwork" includes the inlet air control station in addition to the riser adapter and riser, extending below grade to where the riser penetrates the tank dome. The surface area for the inlet air control station is reduced from $64.2 \mathrm{ft}^{2}$ (value given in the referenced calculations) to account for omission of a spool piece (H-2-85646-070) from the tested volume. The calculated value for $L$ is also dependent on the relative proportions of surface area " $a$ " contributed by ductwork and filter housings. Per the referenced calculations, these account for $47.3 \mathrm{ft}^{2}$ (74\% of 64.2$)$ and $16.9 \mathrm{ft}^{2}(26 \%$ of 64.2$)$, respectively. Thus, based on the above information, the allowable leak rate for acceptance equals:

$$
L_{s}=[(47.3 / 123.9)(1.0)+(16.9 / 123.9)(0.2)] \times(400 / 100)=1.64 \text { SCFM }
$$

The tested volume, which is needed for calculating the actual average leak rate per Data Sheet 2 (Sec. 3.0 of this procedure), is given as $24.7 \mathrm{ft}^{3}$ (WHC 1996b).

\subsection{TEST PREPARATION}

For this test, all of the openings on the inlet air control station will first be sealed off by a safe, suitable means; refer to Figure 1 for general test setup. Connections and access openings will be closed off in the normal manner (i.e., gaskets, door seals, plugs, etc.) where possible. The flow controller and vacuum breaker inlets will be sealed using blankoffs, duct tape, sealants, or other temporary means. The air station will be isolated from the tank using the 12-in. isolation butterfly valve.

The assembly will then be instrumented and pressurized with air to the specified test pressure, inspected for obvious leaks (which may be sealed as necessary), and allowed to stabilize.

\subsection{TEST PROCEDURE}

Record all test data and test exceptions on the Test Data Sheets 1 and 2 and the Record of Test Exception sheets (attached). Initial steps on Data Sheet 1 as they are completed. Note that the sequence of steps 2.3.1 through 2.3.9 may be rearranged at the Test Director's discretion to optimize use of time and resources. The sequence of steps under 2.3 .10 is specific and should not be altered without exception.

2.3.1 Verify that the inlet air control station is configured per Figure 1 , and that the 12-in isolation butterfly valve is in the CLOSED position, isolating the air station from the tank. 
2.3.2 Visually inspect ductwork, housings, filters, connections, gaskets, and seals for signs of damage, component misalignment, improper installation, or other functional problems This is an external inspection only. Ensure that paint is not providing a seal on any connections.

2.3.3 Remove the filter housing doors and inspect the HEPA filter, filter housing, and the filter housing doors and their seals for obvious signs of damage. Note that these components have been examined during the fabrication and final assembly process. This step is only meant as a final soundness check before further testing. Thus, the filters need not be removed for this inspection unless damage is suspected. Repair or replace components as necessary.

2.3.4 Ensure that the HEPA filter has been properly locked against its sealing frame and that the filter housing doors (prefilter and HEPA filter) are secured. Hand tighten door latches in a gradual, equal sequence.

2.3.5 Isolate differential pressure indicators from the tested volume.

2.3.6 Install and seal the temperature measuring instrument into one of the ports on the filter housing assembly (see Figure 1 for recommended

location). Record equipment information on Data Sheet 1 .

2.3.7 Install and seal the pressure measuring instrument into one of the ports on the filter housing assembly (see Figure 1 for recommended location). Record equipment information on Data Sheet 1 .

2.3.8 Install the air supply line (with safety relief mechanism, isolation valve, and pressure reducer) into one of the ports on the filter housing assembly (see Figure 1 for recommended location).

2.3.9 Seal the openings on the vacuum breaker and flow controller per Sec, 2.2.

\subsubsection{Pressure Decay Leak Test}

2.3.10.1 Pressurize test housing/duct assembly to $+7.5 \pm 0.5$ in. w.g. Locate (using a suitable bubble solution) and seal all leaks as practical. Note, on Data Sheet 1 , any remaining leakage from the HEPA filter door and all ports, openings, joints, or connections.

2.3.10.2 Maintain constant pressure until temperature remains constant within $\pm 0.5^{\circ} \mathrm{F}$ for a minimum of 10 minutes.

2.3.10.3 Isolate the air supply from the filter housing while starting the clock. Record the initial pressure and temperature on Data Sheet 1.

2.3.10.4 Record pressure and temperature readings a minimum of once a minute until pressure decays to $75 \%$ of the recorded starting pressure (previous step) or for a maximum of 15 minutes, which ever comes first, on Data Sheet 1 . 
2.3.10.5 Record final time, pressure, and temperature on Data Sheet 1 .

2.3.10.6 Perform the leak rate calculations per Data Sheet 2, and ensure they are verified independently. Verification should be performed by an engineer or other technically competent person.

2.3.10.7 If $Q<L_{s}$ then record "PASS" on Data Sheet 1 . Otherwise, record "RETEST" on Data Sheet 1.

NOTE: If a retest is needed, determine the leak path(s) using the bubble leak location and/or audible leak location method. Repair leaks and perform steps 2.3.10.1 through 2.3.10.7, using new data sheets.

2.3.11 Remove test equipment and temporary blankoff/sealing materiais and reinstall test port plugs. Restore differential pressure indicators to read housing pressures. 
HNF-SD-WM-ATR-177 Rev. 0

\subsection{TEST EXECUTION DATA SHEETS}

DATA SHEET I - POSITIVE PRESSURE DECAY TEST

DATE :

TANK: 241-AN-

RETEST \# :

\begin{tabular}{|c|c|c|}
\hline STEP & DATA/COMMENTS & $\begin{array}{c}\text { TEST DIRECTOR } \\
\text { OR DESIGNEE } \\
\text { INITIALS }\end{array}$ \\
\hline \multicolumn{3}{|l|}{2.3 .1} \\
\hline \multicolumn{3}{|l|}{2.3 .2} \\
\hline \multicolumn{3}{|l|}{2.3 .3} \\
\hline \multicolumn{3}{|l|}{2.3 .4} \\
\hline \multicolumn{3}{|l|}{2.3 .5} \\
\hline 2.3 .6 & (MFR/MODEL/ID\#/CAL. EXP. DATE) & \\
\hline 2.3 .7 & (MFR/MODEL/ID\#/CAL. EXP. DATE) & \\
\hline \multicolumn{3}{|l|}{2.3 .8} \\
\hline \multicolumn{3}{|l|}{2.3 .9} \\
\hline \multicolumn{3}{|l|}{2.3 .10 .1} \\
\hline \multicolumn{3}{|l|}{2.3 .10 .2} \\
\hline 2.3 .10 .3 & START TIME INITIAL PRESSURE (IN WG) INITIAL TEMP (DEG F) & \\
\hline 2.3 .10 .4 & TIME PRESSURE (IN WG) TEMP (DEG F) & \\
\hline 2.3 .10 .5 & FINAL TIME FINAL PRESSURE (IN WG) & \\
\hline 2.3 .10 .6 & (DATA SHEET 2 COMPLETED, HIJH CALCULATIONS INDEPENDENTLY VERIFIED): & \\
\hline 2.3 .10 .7 & & \\
\hline 2.3 .11 & & \\
\hline
\end{tabular}

TEST DIRECTOR (print name and sign):

OTHERS (title, print name and sign): 


\section{DATA SHEET 2 - LEAKAGE RATE CALCULATION}

DATE :

TANK: 241-AN-

RETEST \# :

(A) Beginning pressure in inches WG:

(B) Beginning pressure in psig $(A / 27.7)$ :

(C) Beginning barometric pressure in psi (in. $\mathrm{Hg}$ ) (0.491):

(P1) Beginning duct pressure in psfa $(B+C)(144)$ :

(D) Beginning temperature in deg $\mathrm{F}$ :

(T1) Beginning temperature in $\operatorname{deg} R(D+460)$ :

(E) Ending pressure in inches WG:

(F) Ending pressure in psig (E/27.7):

(G) Ending barometric pressure in psi (in. $\mathrm{Hg})(0.491)$ :

(P2) Ending duct pressure in psfa $(F+G)(144)$ :

(H) Ending temperature in deg $\mathrm{F}$ :

(T2) Ending temperature in $\operatorname{deg} \mathrm{R}(\mathrm{H}+460)$ :

(V) Test Volume in cubic feet (entire assembly shown in $\mathrm{H}-2-85646$, from flow controller to flex connection: $\underline{24.7}$

(R) R, gas constant, in $\mathrm{ft} 1 \mathrm{~b} /(1 \mathrm{~b} * \operatorname{deg} R): \underline{53.35}$

( 4 T) Test Duration in minutes (final time - start time, minutes):

(Q) Average total leak rate per ASME N510-1989, Section 6.5.3.9, in standard $\mathrm{ft}^{3} / \mathrm{min}$ (SCFM) :

$Q=(P 1 / T 1-P 2 / T 2) V /(R * \Delta T * .075)$

\section{$\left(L_{s}\right)$ Allowable Leak Rate: 1.64 SCFM}

Calculations verified: (Checker's initials \& date) 


\subsection{RECORD OF TEST EXCEPTION}

Exception \# of

Date:

Tank Number(s):

Reference ATP Step Number:

\section{EXCEPTION}

DESCRIPTION OF PROBLEM:

ACTION TAKEN :

\section{RESOLUTION}

\begin{tabular}{|l|c|c|}
\hline RESPONSIBILITY/ORGANIZATION & PRINT NAME AND SIGN: & DATE: \\
\cline { 2 - 4 } TESI DIRECIOR: & & \\
\hline COGNIZANT ENGINEER: & & \\
\hline DTHER (INDICAIE TITLE): & & \\
\hline
\end{tabular}

[MAKE ADDITIONAL COPIES AS REQUIRED; ONE EXCEPTION PER SHEET] 
HNF-SD-WM-ATR-177 Rev. 0

APPENDIX B: TEST DATA 
ST $2 / 11 / 9\rangle$

HNF-SD-WM-ATR-177

Rev. 0

Page $B-2$

3.0 TEST EXECUTION DATA SHEETS

DATA SHEET 1 - POSITIVE PRESSURE DECAY TEST

DATE: 29 oCr 96

TANK: 241-AN-101

RETEST \#:

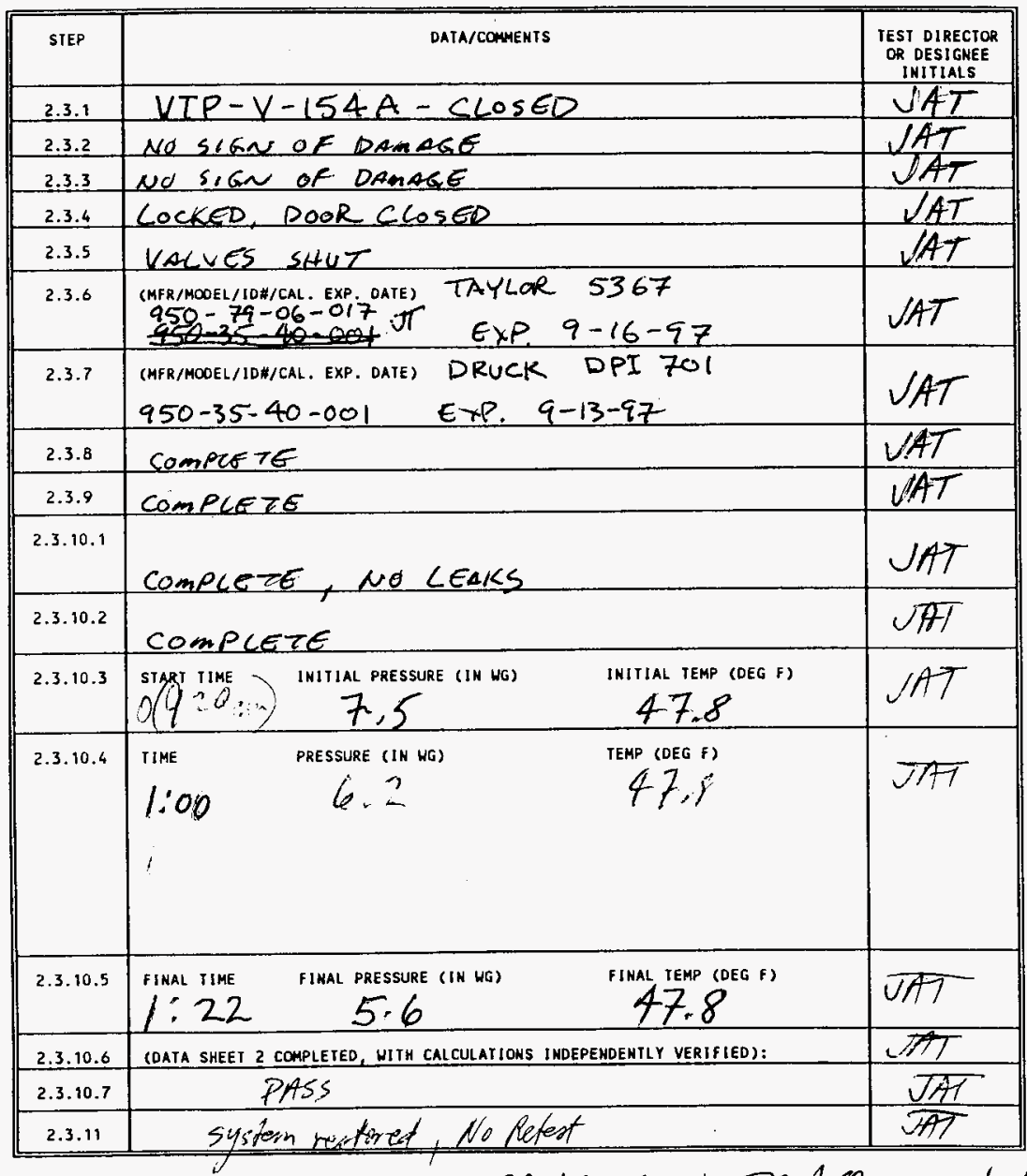

TEST DIRECTOR (print name and sign):CB山ALLGREN CBablgan 10/29/96

OTHERS (title, print name and sign): COG ENG $\$ .7$. Than 10/29/56

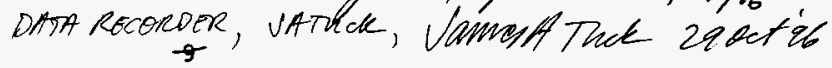

QA: TLL Clams 1/RY/PY 
DATA SHEET 2 - LEAKAGE RATE CALCULATION

\section{DATE: $29 \operatorname{oct}^{\prime} 96$ TANK: 241-AN- 101}

(A) Beginning pressure in inches WG: 7.5

(B) Beginning pressure in psig (A/27.7): 0.2708

(C) Beginning barometric pressure in psi (in. Hg) (0.491): 14.3333 PNL weather $29.19211 / \mathrm{H}$

(P1) Beginning duct pressure in psfa $(B+C)(144)$ : RETEST *:

(D) Beginning temperature in deg $F: 47 . b$

(T1) Beginning temperature in deg $R(D+460): 507.8$

(E) Ending pressure in inches WG: 5.6

(F) Ending pressure in psig (E/27.7): 0.2022

(G) Ending barometric pressure in psi (in. $\mathrm{Hg})(0.491): 14.3333$

(P2) Ending duct pressure in psfa $(F+G)(144): 2093$

(H) Ending temperature in deg $\mathrm{F}: 47.8$

(T2) Ending temperature in $\operatorname{deg} R(H+460)$ : 507.8

(V) Test Volume in cubic feet (entire assembly shown in H-2-85646, from flow controller to flex connection: $\underline{24.7}$

(R) $R$, gas constant, in $\mathrm{ft} 1 \mathrm{~b} /\left(1 \mathrm{~b} \mathrm{~d}^{\star} \mathrm{deg} R\right): \underline{53.35}$

(๑T) Test Duration in minutes (final time - start time, minutes):

$$
1.37 \mathrm{~min}
$$

(Q) Average total leak rate per ASME N510-1989, Section 6.5.3.9, in standard $\mathrm{ft}^{3} / \min$ (SCFM):

$$
\begin{gathered}
Q=\left(\frac{2103-2093}{507.8}\right)(24.7) \div(53.35)(1.37)(0.075) \\
=0.09
\end{gathered}
$$

\section{$\left(L_{s}\right)$ Allowable Leak Rate: 1.64 SCFM}

Calculations verified: (Checker's initials \& date)

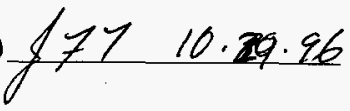


TT 21119?

$$
\begin{array}{r}
\text { HNF-SD-WM-ATR- } 177 \\
\text { Rev. } 0 \\
\text { Page B-4 }
\end{array}
$$

DATA SHEET 1 - POSITIVE PRESSURE DECAY TEST DATE: 29 oc f 96 TANK: 241-AN- 102 RETEST \#:

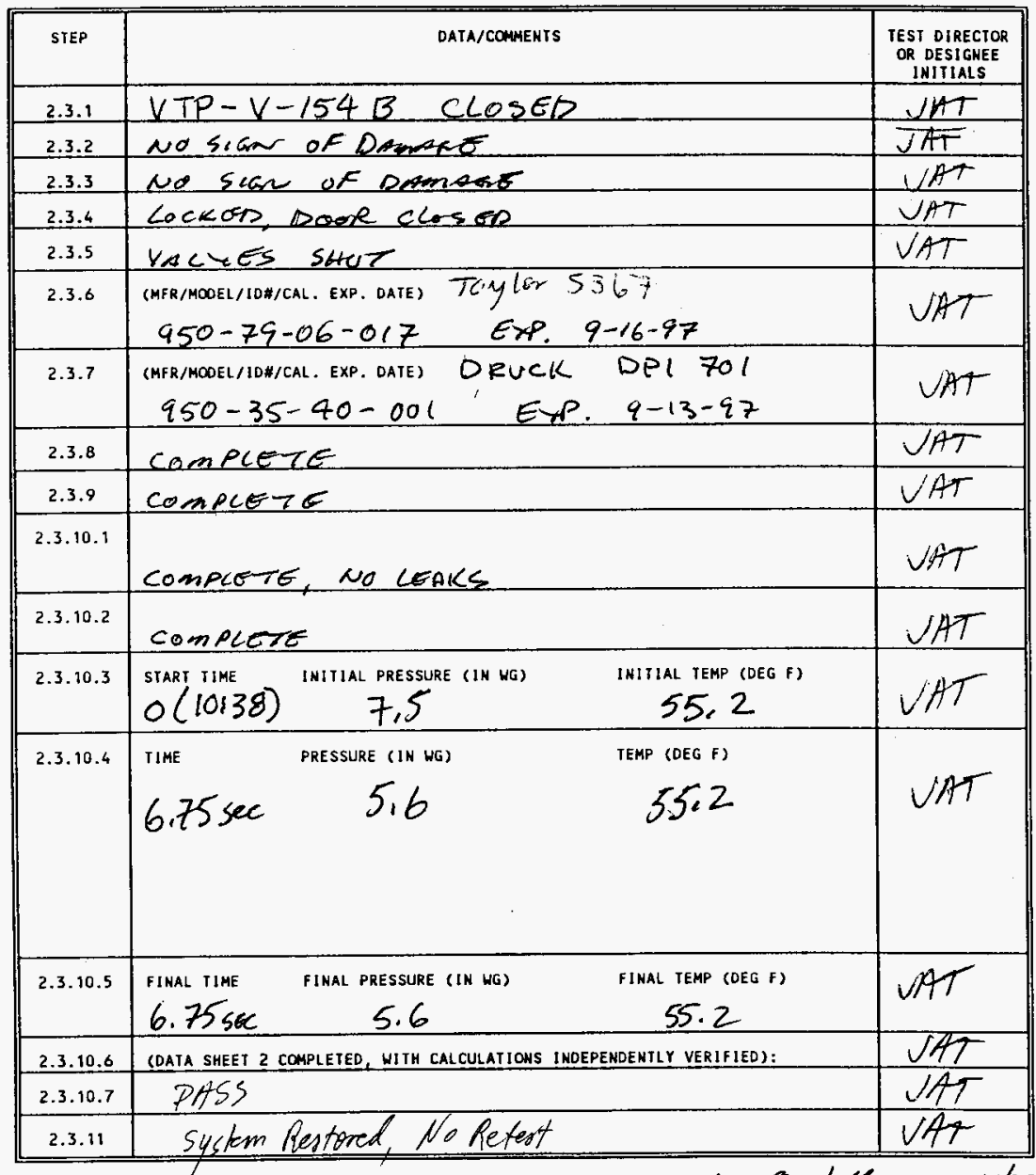

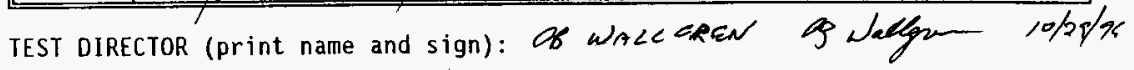
OTHERS (title, print name and sign): coG Ear P.7. Than 10/29/96 DATA RECORDER Names Thule 29 out' 6 - 9 QA: WT Caxpmos/2y/4) 
JT 21197

HNF-SD-WM-ATR- 177

Rev. 0

Page B-5

DATA SHEET 2 - LEAKAGE RATE CALCULATION

DATE: 29 OCT' 96 TANK: 241-AN- 102 RETEST \#:

(A) Beginning pressure in inches WG: 75

(B) Beginning pressure in pig (A/27.7): 0.2708

(C) Beginning barometric pressure in psi (in. Hg)(0.491): $14,345 /$ PUL WEATHER 29.216

(P1) Beginning duct pressure in psia $(B+C)(144): \quad 2105$

(D) Beginning temperature in deg $F: 55,2$

(TI) Beginning temperature in deg $R(0+460): 5 / 5,2$

(E) Ending pressure in inches WG: 5,6

(F) Ending pressure in psis (E/27.7):0.202Z.

(G) Ending barometric pressure in psi (in. $\mathrm{Hg})(0.491): 14,3451$

(P2) Ending duct pressure in psia $(F+G)(144): 2095$

(H) Ending temperature in $\operatorname{deg} \mathrm{F}: 55,2$

(T2) Ending temperature in $\operatorname{deg} R(H+460)$ :

515.2

(V) Test Volume in cubic feet (entire assembly shown in H-2-85646, from flow controller to flex connection: $\underline{24.7}$

(R) $R$, gas constant, in $\mathrm{ft} 1 \mathrm{~b} /(1 \mathrm{~b} * \operatorname{deg} R): \underline{53.35}$

(AT) Test Duration in minutes (final time - start time, minutes):

$6.75 \mathrm{se} \div 60=0.113 \mathrm{~min}$

(Q) Average total leak rate per ASME N510-1989, Section 6.5.3.9, in standard $\mathrm{ft}^{3} / \min (\mathrm{SCFM})$ :

$$
\begin{gathered}
0=\left(\frac{2105-2095}{515.2}\right)(24.7) \div[(53.35)(0.113)(0.075)] \\
=1.06 \mathrm{VAT}
\end{gathered}
$$

$\left(L_{s}\right)$ Allowable Leak Rate: 1.64 SCFM

Calculations verified: (Checker's initials \& date)

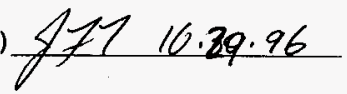




$$
\text { ST } 2 / 1197
$$

$$
\begin{array}{r}
\text { HNF-SD-WM-ATR-177 } \\
\text { Rev. } 0 \\
\text { Page B-6 }
\end{array}
$$

3.0 TEST EXECUTION DATA SHEETS

DATA SHEET 1 - POSITIVE PRESSURE DECAY TEST

DATE: 30 OCT' 96

TANK: 241-AN-103

RETEST \# :

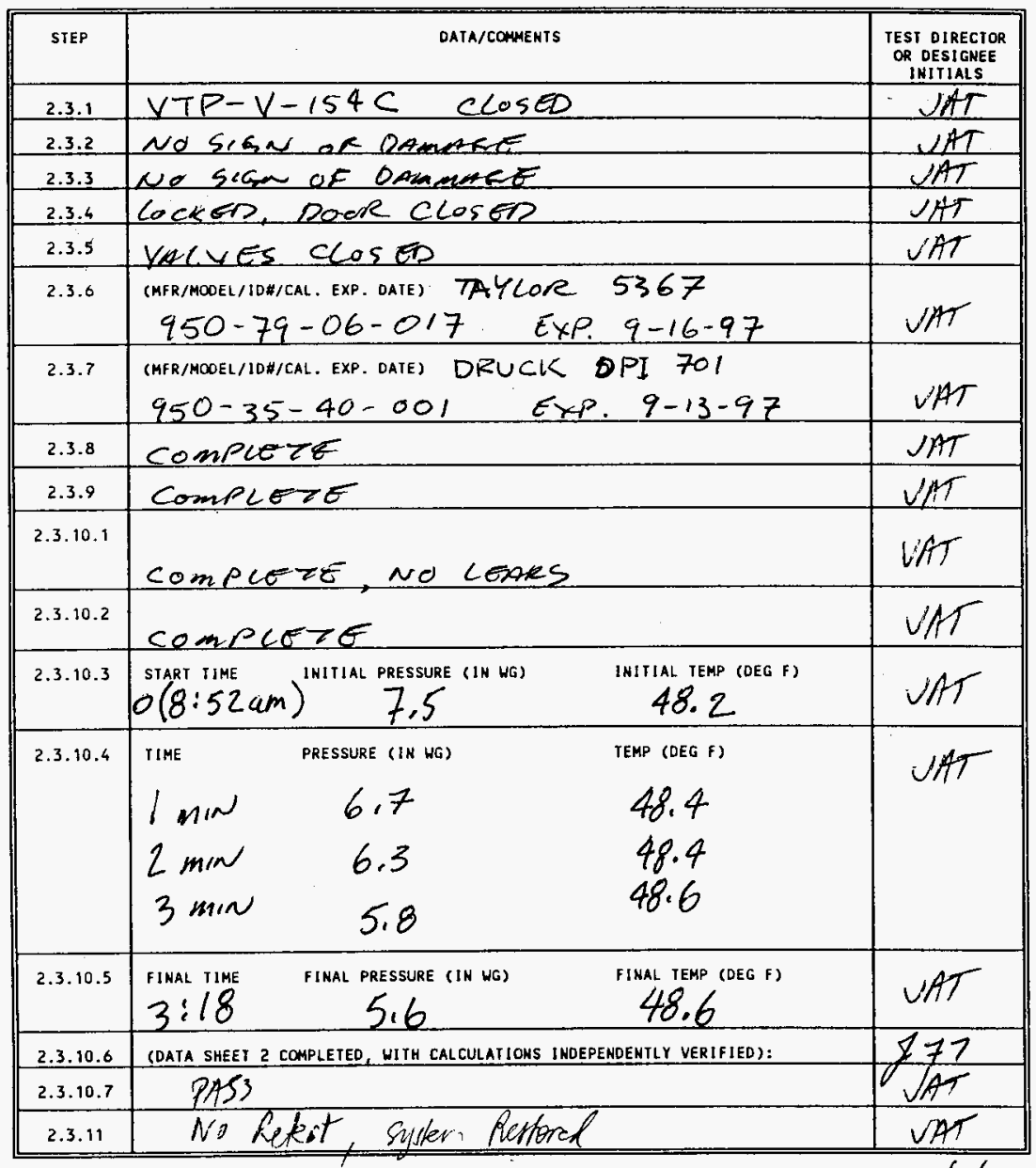

TEST DIRECTOR (print name and sign): COS WACE SEN Co wal gu- 10/so/x OTHERS (title, print name and sign): COG ErG: T.F. THompson L-7. Th am 10.30 .96 DATA RECOKDER, ViA.Tuch, Vamorthuch 30 oct ib QA: The Radioman i/27/or. 


\section{DATA SHEET 2 - LEAKAGE RATE CALCULATION}

DATE: 30 OCT' 96 TANK: 241-AN- 103

RETEST \#:

(A) Beginning pressure in inches WG: 7,5

(B) Beginning pressure in psig (A/27.7): 0.2708

(C) Beginning barometric pressure in psi (in. $\mathrm{Hg})(0.491): 14.4310$

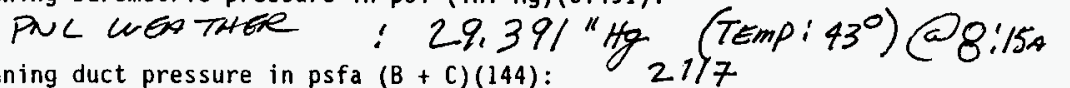

(P1) Beginning duct pressure in psfa $(B+C)(144)$ :

(D) Beginning temperature in deg $F: 48,2$

(TI) Beginning temperature in deg $R(D+460): 508,2$

(E) Ending pressure in inches WG: 5,6

(F) Ending pressure in psig (E/27.7): 0.2022

(G) Ending barometric pressure in psi (in. $\mathrm{Hg})(0.491): 14.4310$

(P2) Ending duct pressure in psfa $(F+G)(144)$ : 2107

( $H$ Ending temperature in deg $F: 48,6$

(T2) Ending temperature in deg $R(H+460)$ :

(V) Test Volume in cubic feet (entire assembly shown in H-2-85646, from flow controller to flex connection: $\underline{24.7}$

(R) $R$, gas constant, in $\mathrm{ft} 1 \mathrm{~b} /(1 \mathrm{~b} * \operatorname{deg} R): \underline{53.35}$

(^T) Test Duration in minutes (final time - start time, minutes):

$$
3.30
$$

(Q) Average total leak rate per ASME N510-1989, Section 6.5.3.9, in standard $\mathrm{ft}^{3} / \mathrm{min}$ (SCFM) :

$Q=(P 1 / T 1-P 2 / T 2) V /(R \star \star T \star .075)$

$$
\begin{gathered}
\left(\frac{2117}{508.2}-\frac{2107}{508.6}\right)(24.7) \div[(53.35)(3.3)(0.075)] \\
=0.04
\end{gathered}
$$

\section{$\left(L_{s}\right)$ Allowable Leak Rate: 1.64 SCFM}

Calculations verified: (Checker's initials \& date) 17/fye 10-30-86 
ST, श1118)

HNF-SD-WM-ATR-177

Rev. 0

Page B-8

3.0 TEST EXECUTION DATA SHEETS

DATA SHEET 1 - POSITIVE PRESSURE DECAY TEST

DATE: 24 JAN. 97 TANK: 241-AN- 104 RETEST \#:

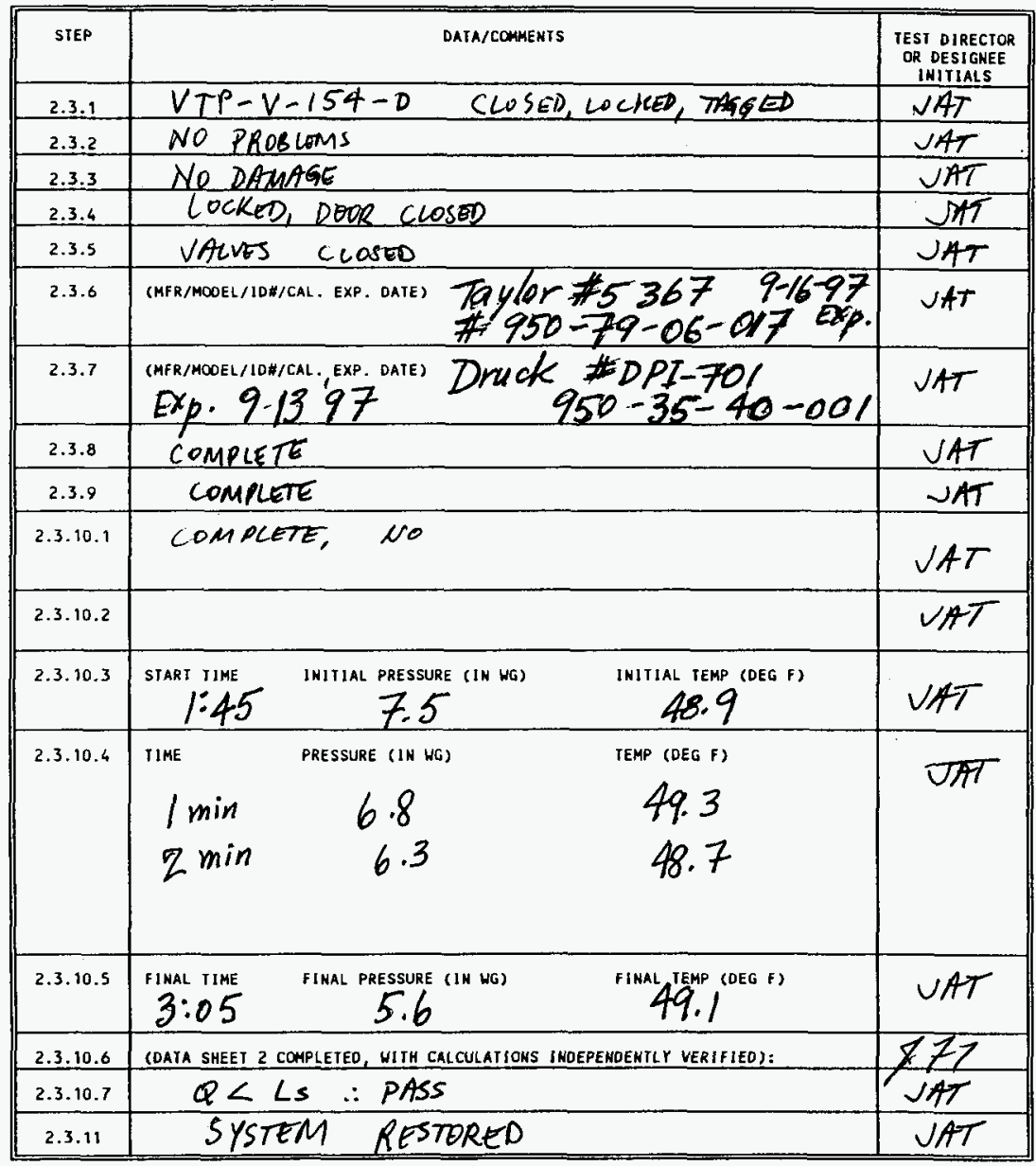

TEST DIRECTOR (print name and sign):R.T. SkAmser TTT8feems $Y / 24 / 97$

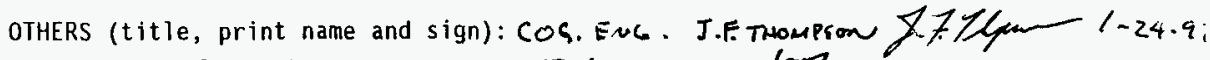
DATA RFCORDED BY V.A. The k, 24 Jami' 97

-9

QA:THK Cedars 1/24/97 


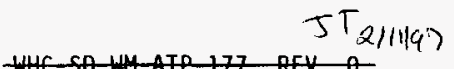

HHESP-WH-ATP 177 AEV. O-
HNF-SD-WM-ATR-I77

Rev. 0

Page B-9

DATE: $24 \operatorname{Jan} .97$ TANK: 241-AN-104

\section{DATA SHEET 2 - LEAKAgE RATE CALCULATION}

RETEST \#:

(A) Beginning pressure in inches WG: 7.5

(B) Beginning pressure in psig (A/27.7): 0.2708

(C) Beginning barometric pressure in psi (in. $\mathrm{Hg}$ ) (0.491):
PNL Weatherman
29. 309 in. $\mathrm{Hg}=$
14. 3907

$(P 1)$ Beginning duct pressure in psfa $(B+C)(144)$ : 2111

(D) Beginning temperature in $\operatorname{deg} \mathrm{F}: 48.9$

(Tl) Beginning temperature in deg $R(D+460)$ : 508.9

(E) Ending pressure in inches WG: 5.6

(F) Ending pressure in psig (E/27.7): 0.2022

(G) Ending barometric pressure in psi (in. $\mathrm{Hg})(0.491)$ :

(P2) Ending duct pressure in psfa $(F+G)(144)$ : 2101

(H) Ending temperature in $\operatorname{deg} F: 49.1$

(T2) Ending temperature in $\operatorname{deg} R(H+460)$ : $50 \% .1$

(V) Test Volume in cubic feet (entire assembly shown in H-2-85646, from flow controller to flex connection: $\underline{24.7}$

(R) $R$, gas constant, in ft $1 \mathrm{~b} /(7 \mathrm{~b} * \operatorname{deg} R): 53.35$

( $\mathrm{T})$ Test Duration in minutes (final time - start time, minutes):

$$
3: 05=3.1 \mathrm{~min} \text {. }
$$

(Q) Average total leak rate per ASME N510-1989, Section 6.5.3.9, in standard $\mathrm{ft}^{3} / \mathrm{min}$ (SCFM) :

$$
\begin{aligned}
Q & =(P 1 / T 1-P 2 / T 2) V /(R * A T * .075) \\
Q= & {\left[\frac{2111}{508.9}-\frac{2101}{509.1}\right](24.7) \div(53.35)(3.1)(0.075) } \\
& =0.042 \text { SCFM - JAT }
\end{aligned}
$$

\section{( $L_{s}$ ) Allowable Leak Rate: 1.64 SCFM}

Calculations verified: (Checker's initials \& date)

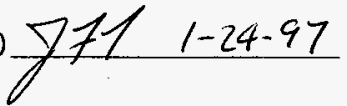




\subsection{TEST EXECUTION DATA SHEETS}

\section{DATA SHEET 1 - POSITIVE PRESSURE DECAY TEST}

DATE: $24 \operatorname{Tan} .97$ TANK: 241-AN-105

RETEST \#:

\begin{tabular}{|c|c|c|}
\hline SIEP & DATA/COMMENTS & $\begin{array}{c}\text { TEST DIRECTOR } \\
\text { OR DESIGNEE } \\
\text { INITIIALS } \\
\end{array}$ \\
\hline 2.3 .1 & Closeg, LOCKEO, & VAT \\
\hline 2.3 .2 & NO PROBLEMS & $\checkmark A T$ \\
\hline 2.3 .3 & NO SIGN OF DRMAGE & UAT \\
\hline 2.3 .4 & LOCKED, DOOR CLOSED & $\sqrt{A T}$ \\
\hline 2.3 .5 & VALVES SHUT & $\checkmark A T$ \\
\hline 2.3 .6 & $\begin{array}{ll}\text { (MFR/MODEL/IDH/CAL. EXP. DATE) } & \text { TAYLOR Model } 5367 \\
\text { EXp. } 9-16-97 & \$ 950-79-06-017\end{array}$ & $\checkmark A T$ \\
\hline 2.3 .7 & $\begin{array}{l}\text { (MFR/MOOEL/1DH/CAL. EXP. DAIE) DRUCK Model DPI-701 } \\
\text { Exp. } 9-19-97 \quad \neq 950-35-40-001\end{array}$ & $\checkmark A T$ \\
\hline 2.3 .8 & COMPCOTE & VIT \\
\hline 2.3 .9 & COMPLETE & VAT \\
\hline 2.3 .10 .1 & COMPLETE; NO LEAKS & $\sqrt{\pi T}$ \\
\hline 2.3 .10 .2 & COMPLETE & VAT \\
\hline 2.3 .10 .3 & $\begin{array}{lcc}\text { Start time } & \text { initial pressure (IN ha) } & \text { imitial temp (DEg } F) \\
11.05 & 7.6 & 39.4 \\
\end{array}$ & $\checkmark A T$ \\
\hline 2.3 .10 .4 & $\begin{array}{lcc}\text { Time } & \text { PRESSURE (IN WG) } & \text { TEMP (DEG } \mathrm{F} \text { ) } \\
1 \text { min } & 5.9 & 39.6 \\
1: 14 & 5.6 & 39.6\end{array}$ & $\checkmark A T$ \\
\hline 2.3 .10 .5 & $\begin{array}{ccc}\text { FINAL TIME } & \text { FINAL PRESSURE (1N WG) } & \text { FIMAL TEMP (DEg F) } \\
1: 14 & 5.6 & 39.6 \\
\end{array}$ & $\checkmark A T$ \\
\hline 2.3 .10 .6 & (OATA SHEET 2 COMPLEIEO, UITH CALCULAILONS INDEPENDENTLY VERIFIED): & $\$ 11$ \\
\hline 2.3 .10 .7 & $Q<L S \quad \therefore$ PASS, NO RETEST & $\checkmark A T$ \\
\hline 2.3 .11 & SYSTEM RESTORED & $\sqrt{A T}$ \\
\hline
\end{tabular}

TEST DIRECTOR (print name and sign): R.T. SKamser VIT Stam $1 / 24(97$ OTHERS (title, print name and sign): COG. ENG. F. F/f/4en J.F Trompson 1.24. DATA RECORDED BY JATTUCK $\rightarrow$ QA: Wx Calama 1/24/97 24 Tan. 97 
ST 211/97

- WHC-SO-HW-ATP-T77 REV - $O$
HNF-SD-WM-ATR-177

Rev. 0

Page B-11

DATE: $24 \operatorname{Jan} .97$ TANK: 241-AN- 105

\section{DATA SHEET 2 - LEAKAGE RATE CALCULATION}

(A) Beginning pressure in inches WG: 7.6

(B) Beginning pressure in psig (A/27.7): 0.2744

(C) Beginning barometric pressure in psi (in. $\mathrm{Hg})(0.491)$ : PNL weather \& $11: 17 \mathrm{~mm} 29.330 \mathrm{in} . \mathrm{Hg}=14.4010$

(P1) Beginning duct pressure in psfa $(B+C)(144)$ :

RETEST \#:

(D) Beginning temperature in deg $\mathrm{F}: 39.4$

(TI) Beginning temperature in deg $R(D+460): 499.4$

(E) Ending pressure in inches WG: 5.6

(F) Ending pressure in psig (E/27.7): 0.2022

(G) Ending barometric pressure in psi (in. $\mathrm{Hg})(0.491): 14,4010$

(P2) Ending duct pressure in psfa $(F+G)(144)$ : 2113

(H) Ending temperature in deg $\mathrm{F}: 39.6$

(T2) Ending temperature in deg $R(H+460)$ : 499.6

(V) Test Volume in cubic feet (entire assembly shown in H-2-85646, from flow controller to flex connection: $\underline{24.7}$

(R) $R$, gas constant, in $\mathrm{ft} 1 \mathrm{~b} /\left(1 \mathrm{~b}{ }^{*} \operatorname{deg} R\right): \underline{53.35}$

( $\mathrm{T}$ ) Test Duration in minutes (final time - start time, minutes):

$$
1: 14=1.23 \mathrm{MIN} \text {. }
$$

(Q) Average total leak rate per ASME N510-1989, Section 6.5.3.9, in standard $\mathrm{ft}^{3} / \min$ (SCFM) :

$$
\begin{aligned}
Q & =(P 1 / T 1-P 2 / T 2) V /(R * \Delta T * .075) \\
Q= & \left(\frac{2113}{499.4}-\frac{2103}{499.6}\right](24.7) \div(53.35)(1.23)(0.075) \\
& =0.109-\text { J4T }
\end{aligned}
$$

\section{(Ls) Allowable Leak Rate: 1.64 SCFM}

calculations verified: (Checker's initials \& date) $11 /-24-97$ 


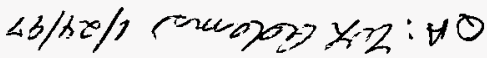

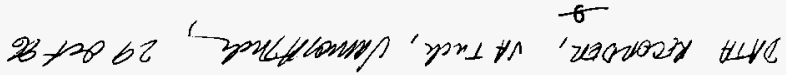

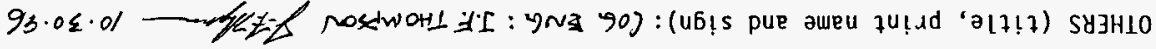

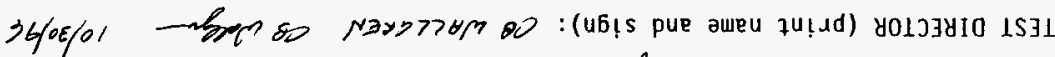

\begin{tabular}{|c|c|c|}
\hline $54^{T}$ & 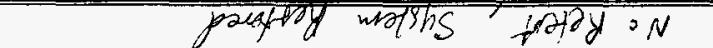 & $11 \cdot \varepsilon \cdot 2$ \\
\hline$-4 / 5$ & $S \quad S \forall d$ & $\angle .01 \cdot \varepsilon \cdot z$ \\
\hline$\angle Z E$ & 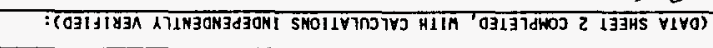 & $\overline{0.01 \cdot 2}$ \\
\hline 261 & 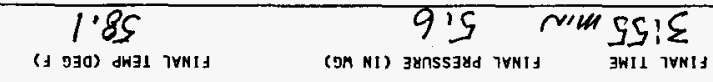 & $5 \cdot 01 \cdot \varepsilon \cdot z$ \\
\hline L4 & 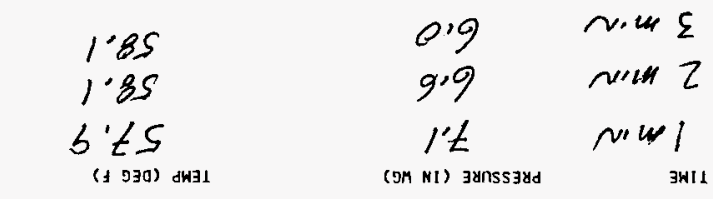 & $7 \cdot 0 l \cdot \varepsilon \cdot z$ \\
\hline 440 & 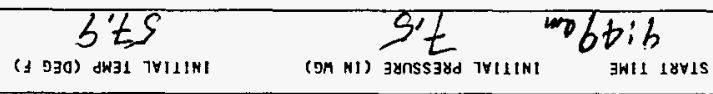 & $\varepsilon \cdot 01 \cdot \varepsilon \cdot z$ \\
\hline 461 & 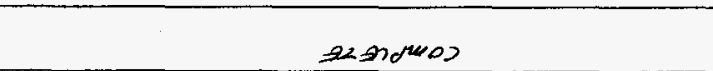 & $z \cdot 01 \cdot \varepsilon \cdot 2$ \\
\hline$\angle \forall \cap$ & 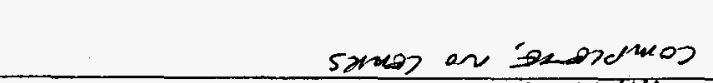 & $1 \cdot 0 t \cdot 2$ \\
\hline 4 ? & 3202 ग्यक्य & $6 \cdot \varepsilon \cdot 2$ \\
\hline 640 & $28225 \operatorname{sen} 5$ & 8.ร.2 \\
\hline 64 & 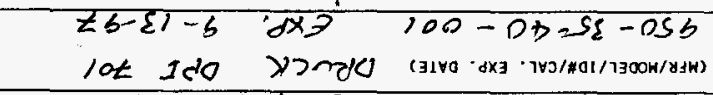 & $\angle \cdot \varepsilon \cdot 2$ \\
\hline 40 & 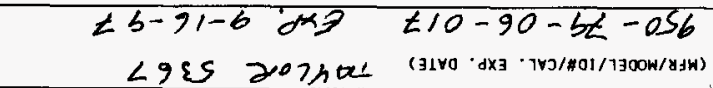 & $g \cdot \varepsilon \cdot z$ \\
\hline -4ी & Lnas s3nगय & $s \cdot \varepsilon \cdot z$ \\
\hline $2+1$ & 8050702000 (cos/20 & $7 \cdot \frac{2}{2 \cdot 5}$ \\
\hline $64 \pi$ & $=2000$ ग 2015 or & $\bar{\varepsilon} \cdot 2$ \\
\hline IIr & श्यूado 70 -20.5 on & $2 \cdot \frac{5}{2} \cdot 2$ \\
\hline $4 \pi$ & ব习501)- & $T \cdot \frac{\varepsilon^{2}}{2}$ \\
\hline 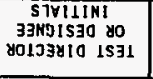 & SIN3HHOJ/VIVO & d31s \\
\hline
\end{tabular}

* 153138

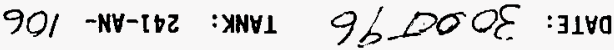

IS3L AY330 JעnSS3Yd JAILISOd - I LJ3HS YIVO

$\operatorname{si-g}$ aged

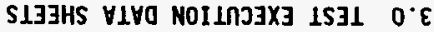

$0 \cdot \wedge$ ay

$\angle L I-Y I \forall-W M-O S-J N H$

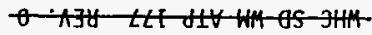

(b) inle is 


\section{DATA SHEET 2 - LEAKAGE RATE CALCULATION}

\section{DATE: 30 COT' 96 TANK: 241-AN- 106}

\section{RETEST *:}

(A) Beginning pressure in inches WG: 7,5

(B) Beginning pressure in psig (A/27.7): 0.2708

(C) Beginning barometric pressure in psi (in. $\mathrm{Hg})(0.491$ ): 14.4334 PNL WEATHER 29.396"Hg@9:20am

(P1) Beginning duct pressure in psfa $(B+C)(144)$ : 2117

(D) Beginning temperature in deg $\mathrm{F}: 57,9$

(T1) Beginning temperature in deg $R(D+460): 5 / 7.9$

(E) Ending pressure in inches WG: 516

(F) Ending pressure in psig (E/27.7): 0.2022

(G) Ending barometric pressure in psi (in. $\mathrm{Hg})(0.491): 14.4334$

(P2) Ending duct pressure in psfa $(F+G)(144): \quad 2107$

(H) Ending temperature in deg $F: 58.1$

(12) Ending temperature in $\operatorname{deg} \mathrm{R}(\mathrm{H}+460)$ :

(V) Test volume in cubic feet (entire assembly shown in H-2-85646, from flow controller to flex connection: $\underline{24.7}$

(R) $R$, gas constant, in ft $1 \mathrm{~b} /\left(1 b^{\star} \operatorname{deg} R\right): \underline{53.35}$

$(\Delta T)$ Test Duration in minutes (final time - start time, minutes):

$$
3.92
$$

(Q) Average total leak rate per ASME N510-1989, Section 6.5.3.9, in standard $\mathrm{ft}^{3} / \mathrm{min}$ (SCFM):

$$
\begin{gathered}
Q=(P 1 / T 1-P 2 / T 2) \mathrm{V} /(R * . T * .075) \\
\left(\frac{2117}{517.9}-\frac{2107}{578.1}\right)(24.7) \div[(53.35)(3.92)(0.075)] \\
=0.03
\end{gathered}
$$

\section{$\left(L_{s}\right)$ Al lowable Leak Rate: 1.64 SCFM}

Calculations verified: (Checker's initials \& date) $10-30-86$ 


$$
\begin{array}{r}
\text { HNF-SD-WM-ATR-177 } \\
\text { Rev. } 0 \\
\text { Page B-14 }
\end{array}
$$

DATA SHEET 1 - POSITIVE PRESSURE DECAY TEST

DATE: $24 \operatorname{JaM} .97$ TANK: 241-AN- 107 RETEST *:

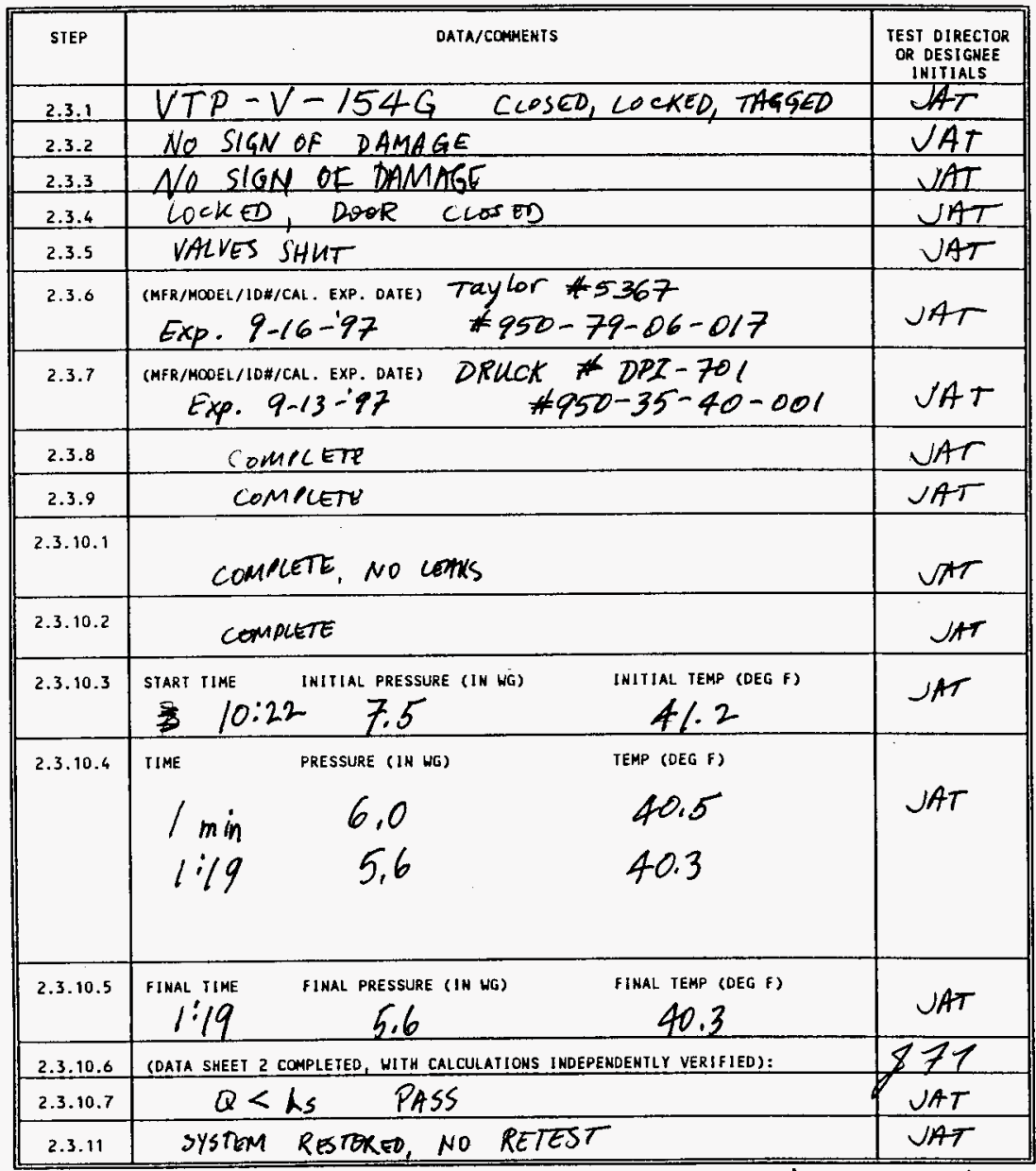

TEST DIRECTOR (print name and sign):RT. skamser $T(T \&$ Sem Y $Y 4 / 97$ OTHERS (title, print name and sign):COG, ENG. J.F. Thompson Filler 1-24-s7

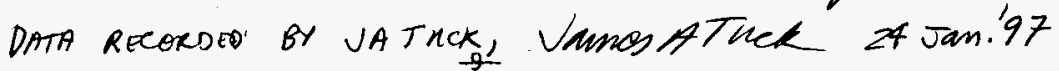
QA: Zeus atoms $1 / 24 / 97$ 
$5 T$ 211197

HNF-SD-WM-ATR-177

Rev. 0

DATA SHEET 2 - LEAKAGE RATE CALCULATION

Page B-15

DATE: $24 \operatorname{Jan} .97$ TANK: 241-AN- 107
(A) Beginning pressure in inches WG: 7.5

RETEST \#:

(B) Beginning pressure in pig (A/27.7): 0.2708

9:55 AM

(C) Beginning barometric pressure in psi (in. $\mathrm{Hg}$ )(0.491): $29.325 \mathrm{in} . \mathrm{Hg}$

(P1) Beginning duct pressure in psf $(B+C)(144): \quad 2 / 12$ PAL WEATHER

(D) Beginning temperature in deg $F: 4 / .2$

(T1) Beginning temperature in deg $R(D+460): 50 / .2$

(E) Ending pressure in inches WG: 5,6

(F) Ending pressure in sig (E/27.7): 0.2022

(G) Ending barometric pressure in psi (in. $\mathrm{Hg})(0.491): 14.3986$

(P2) Ending duct pressure in psia $(F+G)(144): \quad 2 / 03$

(H) Ending temperature in $\operatorname{deg} \mathrm{F}: 40.3$

(T2) Ending temperature in deg $R(H+460): \quad 500.3$

(V) Test volume in cubic feet (entire assembly shown in $\mathrm{H}-2-85646$, from flow controller to flex connection: $\underline{24.7}$

(R) $R$, gas constant, in $\mathrm{ft} 1 \mathrm{~b} /(1 \mathrm{~b} * \operatorname{deg} R): \underline{53.35}$

(₫T) Test Duration in minutes (final time - start time, minutes): $1: 19$

$=1.32 \mathrm{~min}$.

(Q) Average total leak rate per ASME N510-1989, Section 6.5.3.9, in standard $\mathrm{ft}^{3} / \mathrm{min}(\mathrm{SCFM})$ :

$$
\begin{aligned}
Q & =(P 1 / T 1-P 2 / T 2) V /(R * 2 T * .075) \\
Q I & \left(\frac{2112}{501.2}-\frac{2103}{500.3}\right)(24.7) \div(53.35)(1.32)(0.075) \\
& =0.049 \mathrm{sCF}-J A T
\end{aligned}
$$

$\left(L_{s}\right)$ Allowable Leak Rate: 1.64 SCFM

calculations verified: (Checker's initials \& date) $\$ 7 / 1-24-97$ 
DISTRIBUTION SHEET

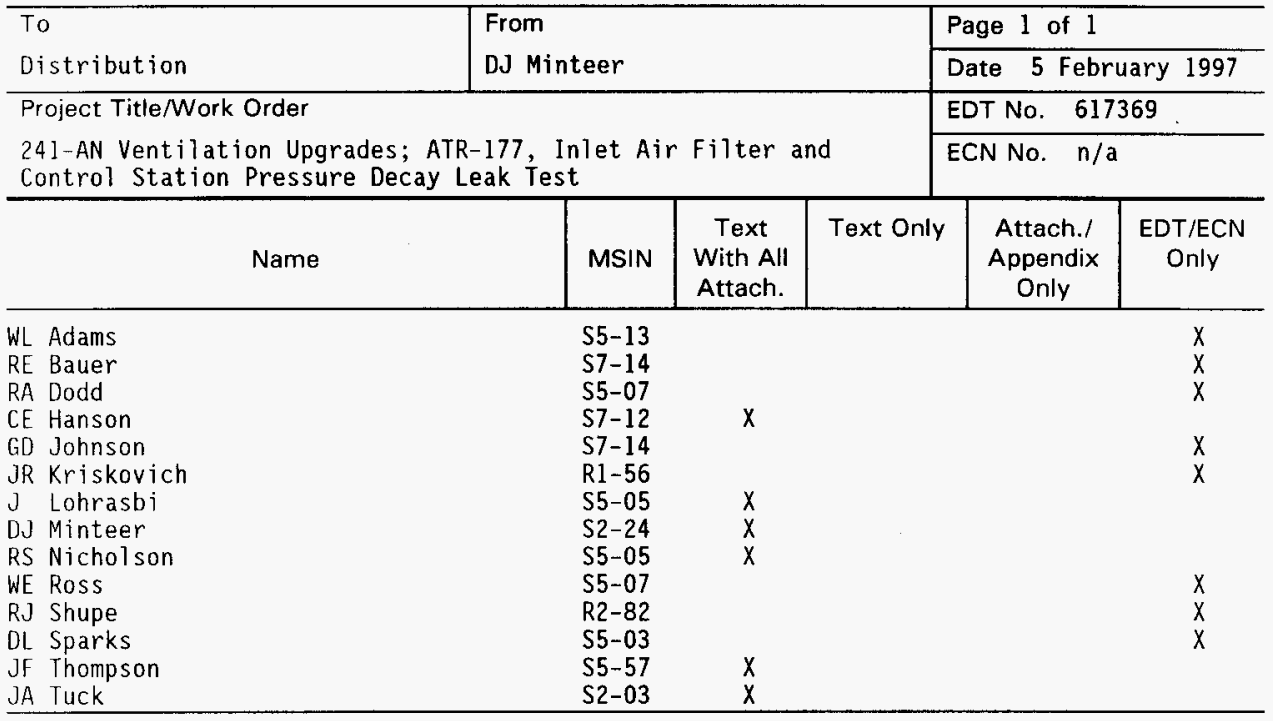

